\title{
Post-treatment sludge analyses and purification of paint effluent by coag-flocculation method
}

\author{
M. C. Menkiti ${ }^{1,2}$ - I. G. Ezemagu ${ }^{2}$ C. I. Nwoye ${ }^{3}$ M. I. Ejimofor ${ }^{2}$
}

Received: 7 May 2015/ Accepted: 22 September 2015/Published online: 18 November 2015

(c) The Author(s) 2015. This article is published with open access at Springerlink.com

\begin{abstract}
Tympanotonos fuscatus shell (T. fuscatus shell), an abundant eco-friendly waste was used as a precursor for the production of Tympanotonos fuscatus coagulant (TFC) for the purification of paint effluent (PE). Tympanotonos fuscatus shells (TFS) are of crustacean origin consisting mainly of chitin, calcium carbonate, entrained protein and other organic matrixes. Influence of $\mathrm{pH}$, dosage and settling time on treatment efficiency was studied. Scanning electron microscopic, Fourier transform infra red, X-ray diffraction and differential scanning calorimetric/thermogravimetric analyses were carried out to investigate, respectively, the surface morphology, functional group, crystalline/lattice structure and thermal stability of TFS, TFC and settled sludge after treatment. The PE was optimally treated at $2 \mathrm{~g} / \mathrm{L}$ TFC dosage, $\mathrm{pH} 5$ and $97 \%$ efficiency. Results indicated that TFC could be an efficient treatment agent for $\mathrm{PE}$ at the conditions of the experiment.
\end{abstract}

Keywords Coagulation/flocculation - Paints effluent . Tympanotonos fuscatus · Sludge

M. C. Menkiti

cmenkiti@yahoo.com; matthew.menkiti@ttu.edu

I. G. Ezemagu

ifegodfey@yahoo.co.uk

C. I. Nwoye

nwoyennike@gmail.com

M. I. Ejimofor

ejohmarc@gmail.com

1 Civil and Environmental Engineering, Water Resources Center, Texas Tech University, Lubbock, TX, USA

2 Department of Chemical Engineering, Nnamdi Azikiwe University, Awka, Nigeria

3 Department of Materials and Metallurgical Engineering, Nnamdi Azikiwe University, Awka, Nigeria

\author{
Abbreviations \\ $K_{\mathrm{B}} \quad$ Boltzmann's constant \\ $K_{m} \quad$ Menkonu coag-flocculation rate constant \\ $K_{\mathrm{R}} \quad$ Von Smoluchowski coag-flocculation constant \\ $\beta_{\mathrm{BR}} \quad$ Collision factor for Brownian transport \\ $\varepsilon_{p} \quad$ Collision efficiency \\ $\tau_{1 / 2} \quad$ Coagulation period/half life \\ $E \quad$ Coag-flocculation efficiency \\ $R^{2} \quad$ Coefficient of determination \\ á Coag-flocculation reaction order \\ $-r \quad$ Coag-flocculation reaction rate \\ $T \quad$ Absolute temperature \\ TFC Tympanotonos fuscatus coagulant \\ TFS Tympanotonos fuscatus shell \\ TSS Total suspended solid \\ TDS Total dissolved solid \\ TS Total solid \\ SSAT Settled sludge after treatment \\ SD Standard deviation \\ PE Paint effluent \\ RMSE Root mean square error \\ SSE Sum of square error \\ RE Relative error \\ $N_{0} \quad$ Concentration of turbidity at time $t=0$ \\ $N_{t} \quad$ Concentration of turbidity at time
}

\section{Introduction}

Paint production is one of the small- and medium-scale enterprises (SME) in Nigeria. Along the production line, hazardous and turbid paint effluent (PE) is generated. The paint effluent generated in the course of production would be toxic and bears suspended particles, odor and color [1]. 
Hence, the need to treat paint effluent to meet Nigeria National Environment (standards for discharge of effluent into water or on land) Regulations standard before discharging to the environment becomes imperative.

Several treatment methods are applied in wastewater treatment, such as adsorption, oxidation process, lime addition, neutralization, membrane filtration, ion exchange, reverse osmosis and coag-flocculation [2].

Among these methods, coag-flocculation using ecofriendly biomaterials present a more viable treatment alternative for initial purification of paint effluent. The advantages of coag-flocculation over other methods include: (1) its simplicity and less energy demand, (2) low cost and (3) reliably robust and efficient [3, 4].

Coagulation is a process of destabilizing particles by a coagulant to promote aggregation by Brownian motion due to action of shear forces [5]. Factors such as $\mathrm{pH}$, quality of raw effluent, nature of effluent and temperature influence coag-flocculation [6].

Fundamentally, chemical coagulants such as ferric chloride, ferric sulfate, ferrous sulfate, alum, polyaluminum and lime have been widely used to coagulate industrial effluents [2]. However, these traditional coagulants have several disadvantages, which include: large volume of sludge [7]; dissolution of metals/constituents into after treatment sludge, under performance and corrosiveness at lower $\mathrm{pH}$ and $\mathrm{pKa}$ (dissociation constant of a solution) [8]. In addition, Miller et al. [9] and Crapper et al. [10], reported that these alum-based chemical coagulants can cause pre-senile dementia in human.

These disadvantages underscore the need for alternative, cost-effective and environmentally friendly substitutes to mineral coagulants, in view of global demand for the consideration of eco-friendly biomaterials. Eco-friendly bio-coagulants are essentially presumed safe for environmental and human health. Being extracts from plants and animals, they are biodegradable and unlikely to produce treated water with extreme $\mathrm{pH}$ [11]. In the age of ozone layer depletion, climate change and widespread environmental degradation, application of these eco-friendly biomaterials in purification of paint effluent is desirable in other to sustain safe global environmental initiatives. Biomaterials such as Nirmali seed [12]; okra [13]; mисuna seed [14]; red bean, sugar and red maize [15]; and Tympanotonos fuscatus shell (TFS) have been identified as coagulants, with the later being the focus of this report.

TFS (images shown in Fig. 1) [16] is composed of natural chitin, which is a major component of the shells of crustacean $[17,18]$. Other components of TFS are calcium carbonate, entrained protein and color pigment. In addition, TFS can also be used for construction and as a source of animal feed [19]. On deacetylation of TFS, it converts to chitosan that constitutes the active coagulation ingredient [11]. TFS are

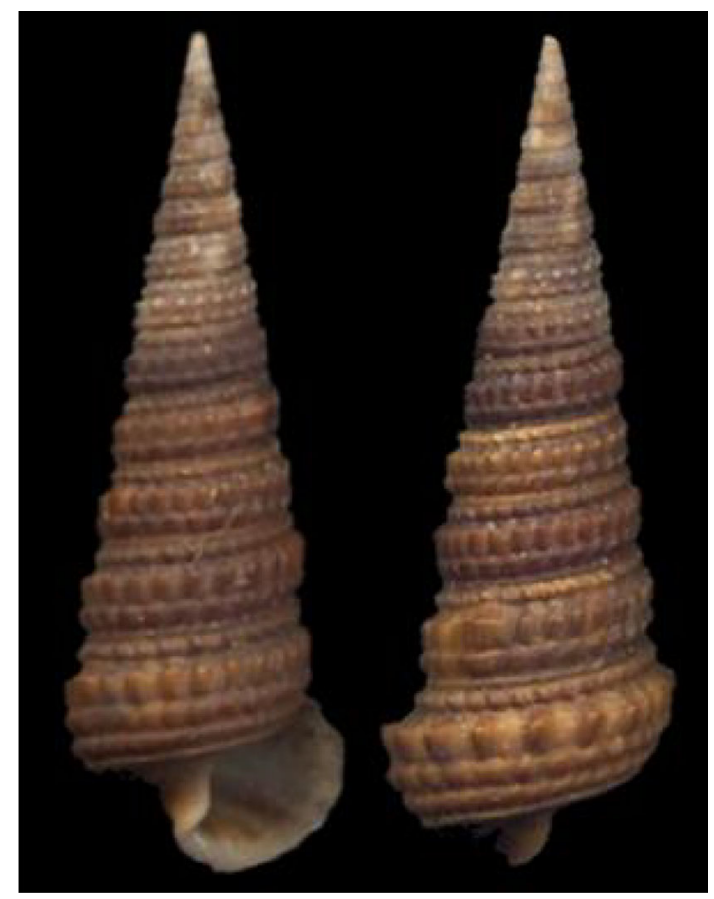

Fig. 1 Images of TFS

huge solid waste in Nigeria and constitute environmental pollutant in producing zones. The utilization of the shells would put this waste to useful ends while also promoting a cleaner environment. The waste shells are obtained after separating the edible flesh from the shells. In this study, the non-food competing TFS had been used as a precursor for the production of TFC, which has been previously subjected to novel trials for the purification of coal washery effluent [20]. Progress made in the previous application necessitated its trial on the purification of $\mathrm{PE}$, which currently constitutes hazard to the environment. Specifically, there is no existing study on the basic characteristics of after treatment sludge generated from biocoagulation of PE using natural extracts. Previous sludge study had generally been on sludge generated from the use of mineral coagulants [21], which could hardly be put to further use due to harmful nature of the mineral coagulants contained in the sludge. To advance the use of SSAT (of bio-extracts), this exploratory study endeavored to give insight into its basic characteristics, its likely further useful potential application and disposal options available to ensure green environment. This current study would close the gaps on previous and current studies that had investigated effluent treatment process without inclusion of basic study on after treatment sludge.

In this work, therefore, the major objectives include focus on the potential application of TFC on treatment of $\mathrm{PE}$ to reduce its turbidity, in addition to the evaluation of the effects of process variables. The coagulation kinetics was also studied as well as chemical and instrumental 
characterization of TFS, TFC and settled sludge after treatment (SSAT). Statistical analyses of the experimental results were also conducted.

\section{Materials and methods}

\section{Material collection}

\section{Paint effluent (PE)}

The paint effluent for the studies was obtained from a factory at Onitsha, Anambra State, Nigeria. The effluent was stored in a black plastic container to prevent changes in the characteristics of the effluent.

\section{TFS and TFC}

TFS used were sourced from Onitsha, Nigeria. It was thoroughly washed, dried, ground and sieved with $0.5 \mathrm{~mm}$ standard sieve to obtain an amount stored in desiccators and further processed to TFC.

In processing TFS to TFC, deproteinization of ground TFS sample was firstly done by agitating continuously $0.5 \mathrm{~L}$ of $1 \mathrm{M} \mathrm{NaOH}$ solution containing $50 \mathrm{~g}$ powdered TFS for $2 \mathrm{~h}$ at $70{ }^{\circ} \mathrm{C}$. On cooling, the mixture was separated and resulting solid sample was washed using distilled water for $30 \mathrm{~min}$ and subsequently dried (at $70{ }^{\circ} \mathrm{C}$ for $2 \mathrm{~h}$ ) using oven. The deproteinized powdered TFS was demineralized for $30 \mathrm{~min}$ in a constantly stirred $0.25 \mathrm{~L}-1 \mathrm{M}$ $\mathrm{HCl}$ solution, and the resulting TFS- $\mathrm{HCl}$ mixture separated by filter paper. The resulting solid residue was washed thoroughly using distilled water for $30 \mathrm{~min}$ and followed by oven drying at $70{ }^{\circ} \mathrm{C}$ for $2 \mathrm{~h}$. The ground TFS obtained after demineralization was deacetylated using autoclave (at $15 \mathrm{psi}$ ) for $30 \mathrm{~min}$ at $122{ }^{\circ} \mathrm{C}$ using $50 \%$ concentrated $\mathrm{NaOH}$ solution, applied at 1:10 (w/v) solid to solution ratio. The sample produced after autoclaving was washed to $\mathrm{pH} 7$ using running distilled water and subsequently oven dried for $2 \mathrm{~h}$ at $70{ }^{\circ} \mathrm{C}$. This processed end product of ground TFS was termed TFC.

\section{Material characterization}

\section{Analysis of physical properties of $P E$}

The wastewater characterization was based on American Public Health Association (APHA) procedures [22].

\section{Analysis of physiochemical properties of TFC}

Percentage yield/weight loss $90 \mathrm{~g}$ of TFS was weighed and processed to TFC of weight $A$. Thus,
Percentage yield $=\frac{A}{90} \times 100$

Percentage weight loss $=\frac{90-A}{90} \times 100$.

Bulk density $W$ weight of TFS was used to fill up a container of $1000 \mathrm{~mL}$. Thus,

Bulk density $=\frac{W}{V}$

where $W$ is weight of the TFS and $V$ is volume of the container.

Percentage ash content $4 \mathrm{~g}$ of the dried TFS was burnt in a muffle furnace at $600{ }^{\circ} \mathrm{C}$ to yield gray-white residue. Thus,

Ash content $(\%)=\frac{W_{\text {ash }}}{W_{\text {sample }}} \times 100$

where $W_{\text {ash }}$ is weight of ash and $W_{\text {sample }}$ is weight of TFS sample.

Percentage oil content $20 \mathrm{~g}$ of powdered TFS was wrapped in a filter paper and placed in a Soxhlet extractor attached to a round bottom flask containing $150 \mathrm{~mL}$ of hexane. Heat was applied to the set up and extraction is considered complete when the extracting solution becomes clear. The extract (oil) was left for 7 days to evaporate entrained solvent. Thus,

$\%$ Oil yield $=\frac{W_{\text {oil }}}{W_{\text {sample }}} \times 100$

where $W_{\text {oil }}$ is the weight of oil and $W_{\text {sample }}$ is the weight of sample.

Percentage moisture content $2 \mathrm{~g}$ of TFS was heated in oven at $160{ }^{\circ} \mathrm{C}$ for $6 \mathrm{~h}$ and measured to a constant weight. Thus,

$\%$ Moisture content $=\frac{W_{\text {sample }}-W_{\text {dry }}}{W_{\text {sample }}} \times 100$

where $W_{\text {sample }}$ is the weight of precursor before drying, $W_{\text {dry }}$ is weight of precursor after drying.

Percentage protein content $2 \mathrm{~g}$ of TFS flour was put into a Kjeldahl digestion flask containing $8 \mathrm{~g}$ of catalyst $(96 \%$ anhydrous $\mathrm{Na}_{2} \mathrm{SO}_{4}, 3.5 \% \mathrm{CuSO}_{4} \cdot 5 \mathrm{H}_{2} \mathrm{O}, 0.5 \%$ Selenium dioxide). $10.1 \mathrm{~mL}$ of conc. $\mathrm{H}_{2} \mathrm{SO}_{4}$ was added to the flask and shaken occasionally for $2 \mathrm{~h}$. $50 \mathrm{~mL}$ of boric acid solution $(2 \%)$ and screened methyl red indicator were added to the flask after cooling. The apparatus was connected with the delivery tube deepened below the boric acid solution. $50 \% \mathrm{NaOH}$ solution was added to alkalize 
the digest. $50 \mathrm{~mL}$ each of the distillate and a blank were titrated under same conditions using 0.1 M H2SO4. Thus,

$\%$ Nitrogen $=$ volume of $0.1 \mathrm{M} \mathrm{H}_{2} \mathrm{SO}_{4}$

Protein content $=\%$ nitrogen $\times 6.25$

Instrumental characterization of TFS, TF and SSAT The surface morphology, functional groups and lattice/crystalline structure of the samples were determined using model Zeiss Evo ${ }^{\circledR}$ MA 15 EDX/WDS microscope, Model 470/670/870 Thermo Nicolet Nexus unit and PHILIPS X PERT X-RAY unit, respectively. Thermal characteristics of samples were analyzed using models TGA-Q50 and DSC-Q200 units.

\section{Coag-flocculation factors impact}

Influence of TFC dosage variation

1. Native $\mathrm{pH}$ and initial particle load on the paint effluent (PE) were measured at ambient temperature.

2. Samples of $1000 \mathrm{~mL}$ of PE in ten different $1000-\mathrm{mL}$ beakers were fed with $0.5-5 \mathrm{~g} / \mathrm{L}$ Tympanotonos fuscatus coagulant (TFC).

3. The PE/TFC in the $1000-\mathrm{mL}$ beakers were firstly subjected to rapid mixing (110 rpm for $2 \mathrm{~min}$ ) and followed by slow mixing ( $35 \mathrm{rpm}$ for $20 \mathrm{~min}$ ). At the expiration of slow mixing, the PE/TFC supernatants were brought down and allowed to stand for $30 \mathrm{~min}$.

4. At $30 \mathrm{~min}, 15 \mathrm{~mL}$ of the supernatant was taken at $2 \mathrm{~cm}$ depth from each of the beakers and drained into cuvettes.

5. The residual turbidity of supernatants was determined. Particle concentration was calculated as a product of turbidity (NTU) and $T_{f}$. $T_{f}$ is a conversion factor that converts turbidity to particle concentration. $T_{f}$ has a value of 2.35 [23].

\section{Influence of $P E p H$ variation}

1. Samples of optimum dosage from "Influence of TFC dosage variation" were charged into 8 beakers containing $1000 \mathrm{~mL}$ of PE each. Native $\mathrm{pH} 8$ of PE was adjusted from 2 to 9 using $0.1 \mathrm{M} \mathrm{H}_{2} \mathrm{SO}_{4}$ and $0.1 \mathrm{M}$ $\mathrm{NaOH}$ prior to dosing.

2. Steps (3)-(5) of "Influence of TFC dosage variation" were repeated.

\section{Influence of time on removal efficiency}

1. Sample of optimum dosage was fed into $1000 \mathrm{~mL}$ PE.

2. Step (3) of "Influence of TFC dosage variation" was repeated. While settling, residual turbidity values were recorded at 3-30 min based on "Influence of TFC dosage variation".

\section{Coagulation kinetics theory}

For the cases of monodisperse, no break up and biparticle collisions [24-26]:

$\frac{\mathrm{d} n_{k}}{\mathrm{~d} t}=\frac{1}{2} \sum_{i+j=k} \beta_{\mathrm{BR}}(i, j) n_{i} n_{j}-\sum_{i=1}^{\infty} \beta_{\mathrm{BR}}(i, k) n_{i} n_{k}$

where $\frac{\mathrm{d} n k}{\mathrm{~d} t}$ is the coag-flocculation rate. $\beta_{\mathrm{BR}}(i, j)$ represents coag-flocculation transport mechanism. $n_{i}$ and $n_{j}$ are concentrations for particles of size $i$ and $j$, respectively. $\beta_{\mathrm{BR}}$ [27] is defined by Eq. 10:

$\beta_{\mathrm{BR}}=\frac{8}{3} \varepsilon_{P} \frac{K_{\mathrm{B}} T}{\eta}$

where $K_{\mathrm{B}}$ is Boltzmann's constant $(J / K), T$ is absolute temperature $(\mathrm{K}), \varepsilon_{p}$ is the collision efficiency, $\eta$ is the viscosity of the fluid.

For rapid coagulation

$K_{\mathrm{R}}=8 \pi a D^{\prime}$

where $K_{\mathrm{R}}$ is the Von Smoluchowski rate constant for rapid coagulation [28], $a$ is particle radius and $D^{\prime}$ is diffusion coefficient.

Equation 11 is simplified to

$K_{\mathrm{R}}=\frac{4}{3} \frac{K_{\mathrm{B}} T}{\eta}$

Equations 10-12 can be transformed to Eq. 13 [14]:

$K_{m}=\frac{1}{2} \beta_{\mathrm{BR}}$

where $K_{m}$ is Menkonu coagulation-flocculation rate constant. For Brownian aggregation, rate could also be [26, 29]:

$-\frac{\mathrm{d} N_{t}}{\mathrm{~d} t}=K_{m} N_{t}^{\alpha}$

$N_{t}$ is the total particle concentration at time $t$. Also, for rapid coag-flocculation $1 \leq \alpha \leq 2$ [30].

Thus,

for $\alpha=1: \operatorname{In}\left(\frac{1}{N}\right)=K_{m} t-\operatorname{In} N_{0}$

for $\alpha=2: \frac{1}{N}=K_{m} t+\frac{1}{N_{0}}$

where $N_{0}$ is the initial $N_{t}$ at time $=0 . N$ is $N_{t}$ at upper time limit $>0$. Plot of $\frac{1}{N}$ vs $t$ produces a slope of $K_{m}$ and intercept of $\frac{1}{N_{0}}$.

For coagulation period $\tau_{1 / 2}$ Eq. 16 yields Eq 17: 


$$
\tau_{1 / 2}=1 /\left(0.5 N_{0} K_{m}\right) .
$$

Equation 18 gives coagulation-flocculation efficiency

$$
E(\%)=\left[\frac{N_{0}-N_{t}}{N_{0}}\right] 100 .
$$

\section{Statistical analyses}

Standard deviation and the statistical error analyses were calculated using Eqs. 19-20 and 21-23, respectively; where $A_{\mathrm{v}}$, SD, RMSE, SSE and RE are the average mean, standard deviation, root mean square error, sum of square error and relative error, respectively.

$A_{\mathrm{v}}=\sum\left(\frac{q_{i_{\mathrm{exp}}}}{N_{i}}\right)$

$\mathrm{SD}=\sqrt{\frac{1}{N_{i}} \sum\left(q_{i_{\text {exp }}}-A_{\mathrm{v}}\right)^{2}}$

$\mathrm{RMSE}=\sqrt{\frac{1}{N} \sum_{i=1}^{N}\left(\left(\frac{q_{i_{\mathrm{exp}}}-q_{i_{\mathrm{cal}}}}{q_{i_{\text {exp }}}}\right)^{2}\right)}$

$\operatorname{SSE}=\sum\left(q_{i_{\text {exp }}}-q_{i_{\text {cal }}}\right)$

$\mathrm{RE}=\frac{100}{N} \sum_{i=1}^{N}\left(\frac{q_{i_{\mathrm{exp}}}-q_{i_{\mathrm{cal}}}}{q_{i_{\mathrm{exp}}}}\right)$

where $q_{i_{\text {exp }}}$ and $q_{i_{\text {cal }}}$ are the obtained experimental and predicted data.

\section{Results and discussion}

\section{Characterization results}

\section{Physiochemical characteristics}

Table 1 shows the values for total suspended solids (TSS), total dissolved solids (TDS) and total solid (TS) that are significant for the application of coagulation.

Table 2 shows that the yield value $(80 \%)$ and protein content $(17 \%)$ are quite significant. Hence, TFS can be considered a suitable precursor.

\section{SEM and elemental analyses of TFS, TFC and SSAT}

Pairs of SEM images of TFS, TFC and SSAT are shown as Figs. 2a, b, 3a, b and $4 \mathrm{a}, \mathrm{b}$, respectively. Figure $2 \mathrm{a}$ shows image of a single, magnified, irregular-shaped particle surrounded with dark field void. Similar heavily compact particles distribution is observed in Fig. $2 b$. Figure $2 b$ shows the structure of smooth and sparsely dispersed sticklike particles surrounded by completely cemented pores.
Table 1 Characterization of paint effluent (PE)

\begin{tabular}{lll}
\hline Parameter & Value & NESRA \\
\hline TSS & $2679 \mathrm{mg} / \mathrm{L}$ & $100 \mathrm{mg} / \mathrm{L}$ \\
PH & 8 & $5-8$ \\
TDS & $1600 \mathrm{mg} / \mathrm{L}$ & $1200 \mathrm{mg} / \mathrm{L}$ \\
TS & $4279 \mathrm{mg} / \mathrm{L}$ & $1300 \mathrm{mg} / \mathrm{L}$ \\
\hline
\end{tabular}

National Environment (standards for discharge of effluent into water or on land) Regulations, (NESRA) S.I. No 5/1999

Table 2 Tympanotonos fuscatus shell proximate analysis

\begin{tabular}{ll}
\hline Parameter & Value \\
\hline Yield (\%) & 80 \\
Weight loss $(\%)$ & 20 \\
Bulk density $(\mathrm{g} / \mathrm{mL})$ & 0.12 \\
Ash content $(\%)$ & 4.98 \\
Oil content $(\%)$ & 10 \\
Moisture content $(\%)$ & 4.5 \\
Protein $(\%)$ & 17.7 \\
\hline
\end{tabular}

Figure $3 \mathrm{a}, \mathrm{b}$ shows images of sponge-like structure with voided pores scattered evenly on the surface of the structure. The morphology is white field unlike the TFS. The presence of the voided pores in TFC allowed for the trapping of particles within the pores surfaces. Figure 4 shows the images of SSAT with filled pores due to the deposition of particles. The filling of the pores noted could be linked to results displayed in Table 3 .

Table 3 indicates that $\mathrm{Ti}, \mathrm{Fe}, \mathrm{Cu}, \mathrm{Cl}, \mathrm{Al}$ were absent in Tympanotonos fuscatus shell (TFS) but maintained presence in TFC and settled sludge after treatment (SSAT). More quantities of $\mathrm{Na}, \mathrm{Mg}, \mathrm{Al}, \mathrm{Si}, \mathrm{Cl}$ and $\mathrm{Ca}$ were contained in TFC when compared to TFS. The decrease in $\mathrm{K}$, $\mathrm{Al}$ and $\mathrm{Cl}$ could be linked to the use of the elements for the formation of salts that filled significant voids in TFC as shown in SSAT images. It could be taught that chlorine present in the paint effluent (PE) took active part in the formation of the salt $[31,32]$ and subsequent depletion of $\mathrm{Na}, \mathrm{K}$ and $\mathrm{Al}$.

\section{FTIR spectra analysis of TFS, TFC and SSAT}

Figure 5 shows that spectra of TFS, TFC and SSAT exhibit 30,19 and 22 discernible peaks at frequency of $600-4000 \mathrm{~cm}^{-1}$ with a threshold of $0.44,1.17$ and 0.88 , respectively [33]. In Fig. 3a, $3335 \mathrm{~cm}^{-1}$ (N-H stretching) depicts the presence of secondary amine, supporting the presence of protein in TFS. $2919 \mathrm{~cm}^{-1}$ denotes $\mathrm{C}-\mathrm{H}$ stretching while 1652,1646 and $1635 \mathrm{~cm}^{-1}$ denote $\mathrm{C}=\mathrm{C}$ stretching and $\mathrm{NH}_{2}$. Peaks at 1463,1455 and $1447 \mathrm{~cm}^{-1}$ indicate the presence of $\mathrm{N}=\mathrm{N}$ stretching. $1034-1082 \mathrm{~cm}^{-1}$ 

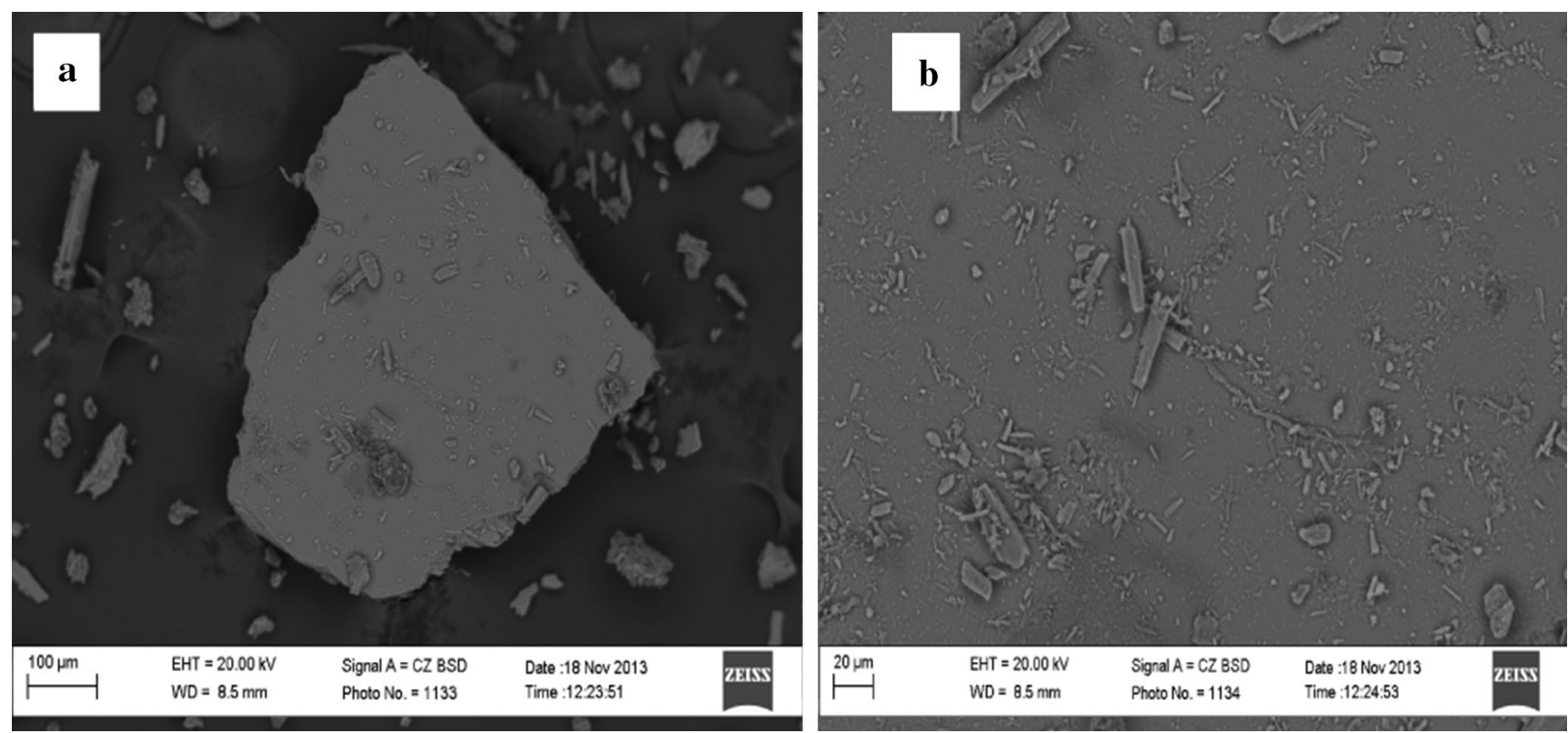

Fig. 2 SEM images of Tympanotonos fuscatus shell (TFS)
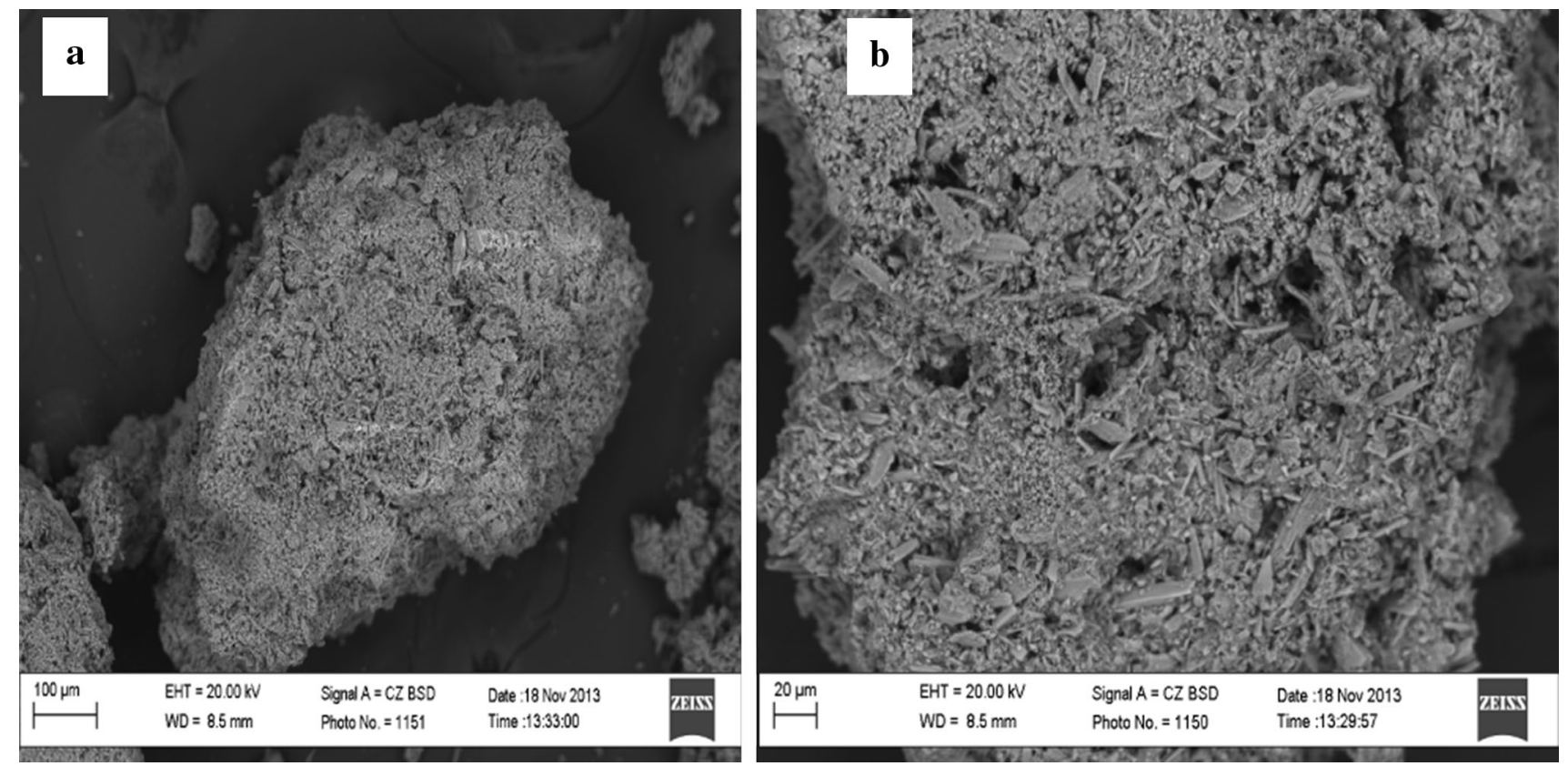

Fig. 3 SEM images of Tympanotonos fuscatus coagulant (TFC)

are characterized by $\mathrm{C}-\mathrm{O}$ stretching. Peaks at 856,712 and $700 \mathrm{~cm}^{-1}$ characterize $\mathrm{NH}_{2}$ wagging and twisting, $\mathrm{N}-\mathrm{H}$ wagging and $=\mathrm{C}-\mathrm{H}$ bending, respectively. In Fig. 5b, peaks at $3850-3593 \mathrm{~cm}^{-1}(\mathrm{O}-\mathrm{H}$ stretching) are attributed to the presence of phenol and alcohol while band at $3296 \mathrm{~cm}^{-1}(\mathrm{~N}-\mathrm{H}$ stretching) indicates the presence of secondary amide groups. 2916 and $2850 \mathrm{~cm}^{-1}$ (methylene asymmetric and symmetric $\mathrm{C}-\mathrm{H}$ stretching) indicate the presence of aliphatic hydrocarbon groups. For 1634 to $1443 \mathrm{~cm}^{-1}, \mathrm{C}=\mathrm{C}$ stretching, $\mathrm{NH}_{2}$ scissoring, azo compound and $\mathrm{N}-\mathrm{H}$ bending are indicated. Broad bands at 1082, 1068 and $1032 \mathrm{~cm}^{-1}$ indicate $\mathrm{C}-\mathrm{O}$ stretching. Peaks 

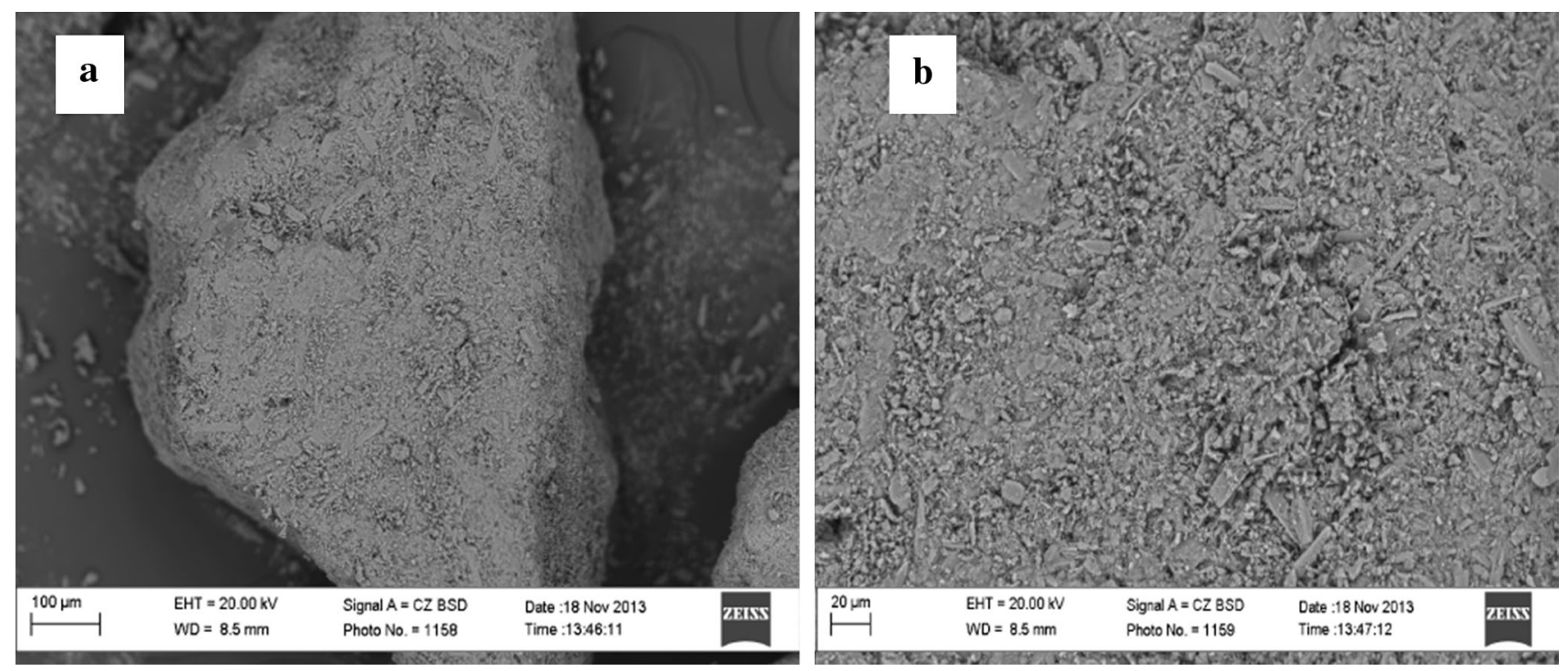

Fig. 4 SEM images of settled sludge after treatment (SSAT)

Table 3 Elemental composition of TFS, TFC and SSAT

\begin{tabular}{lrrr}
\hline Element $(\mathrm{Wt} \%)$ & \multicolumn{1}{c}{ TFS } & \multicolumn{1}{c}{ TFC } & SSAT \\
\hline $\mathrm{C}$ & 23.68 & 17.47 & 20.51 \\
$\mathrm{Na}$ & 0.99 & 31.65 & 5.14 \\
$\mathrm{Mg}$ & 0.68 & 3.18 & 18.63 \\
$\mathrm{Al}$ & 0.00 & 3.16 & 9.32 \\
$\mathrm{Si}$ & 0.00 & 4.49 & 11.49 \\
$\mathrm{P}$ & 0.00 & 0.00 & 0.00 \\
$\mathrm{~S}$ & 0.00 & 0.00 & 0.00 \\
$\mathrm{Cl}$ & 0.00 & 0.81 & 0.49 \\
$\mathrm{~K}$ & 0.00 & 0.19 & 0.00 \\
$\mathrm{Ca}$ & 195.77 & 153.69 & 127.17 \\
$\mathrm{Ti}$ & 0.00 & 0.00 & 8.38 \\
$\mathrm{Fe}$ & 0.00 & 1.91 & 5.51 \\
$\mathrm{Cu}$ & 0.00 & 0.00 & 0.00 \\
$\mathrm{O}$ & 78.93 & 83.07 & 93.36 \\
\hline
\end{tabular}

at $909,855,781,712$ and $699 \mathrm{~cm}^{-1}\left(\mathrm{~N}-\mathrm{H}\right.$ stretching, $\mathrm{NH}_{2}$ wagging and twisting, $\mathrm{N}-\mathrm{H}$ wagging and $=\mathrm{C}-\mathrm{H}$ bending) indicate the presence of amine and alkyne groups. Figure $5 \mathrm{c}$ shows distinct peaks at $1445 \mathrm{~cm}^{-1}(\mathrm{~N}=\mathrm{N}$ stretching), $3335 \mathrm{~cm}^{-1}$ (N-H stretching), 2917, $2850 \mathrm{~cm}^{-1}$ (methylene symmetric and asymmetric of $\mathrm{C}-\mathrm{H}$ stretching). Peaks at $1082,1068,1032$ and $1009 \mathrm{~cm}^{-1}$ indicate the presence of esters, while $913,857 \mathrm{~cm}^{-1}$ stand for $\mathrm{N}-\mathrm{H}$ stretching and $\mathrm{NH}_{2}$ wagging and twisting. The region of $712-699 \mathrm{~cm}^{-1}$ depicts the presence of alkyne group. Figure $5 \mathrm{a}-\mathrm{c}$ showed that some peaks were shifted and also new peaks were detected.

\section{XRD pattern of TFS, TFC and SSAT}

Figure 6a-c shows 11 and 10 clear peaks, respectively. The peaks were assigned on the bases of their different reflections and planes. The left-right shifts might be linked to the expansion or contraction of the samples. The intense peaks for samples were caused by a small subset of crystallite in the powder that had a plane oriented exactly parallel to the reference plane. The system depicted $000 \mathrm{hkl}$ for TFS, TFC and SSAT. This implies that the atomic structures of TFS, TFC and SSAT are of primitive crystalline structure.

\section{Differential scanning calorimetric (DSC)}

and thermogravimetric analyses (TGA) of TFS, TFC and SSAT

DSC and TGA indicate the thermal characteristics of samples [34-36] in Figs. 7-9. Figures 7a and 8a show the DSC profile for TFS and TFC over $37.5-296.875{ }^{\circ} \mathrm{C}$ and $37.5-297{ }^{\circ} \mathrm{C}$, with enthalpy of 12.039 and $11.439 \mathrm{~kJ} / \mathrm{mol}$, respectively. The transition could be due to de-stringing and coiling of carbon chain resulting in spontaneous densification [37, 38]. Densification depicted in Figs. 7a and $8 \mathrm{a}$, respectively, took place at $150-200{ }^{\circ} \mathrm{C}$ and 112.5-187.5 ${ }^{\circ} \mathrm{C}$ exothermically. The final residual mass for TFS (Fig. 7b) and TFC (Fig. 8b) was $3.259 \mathrm{mg}$ and $3.520125 \mathrm{mg}$, representing 94.06 and $87.5 \%$ of the original weights, respectively. The early and late weight losses in Figs. $7 \mathrm{~b}$ and $8 \mathrm{~b}$ were due to loss of internal moisture and labile component, respectively, from samples [37, 38]. 

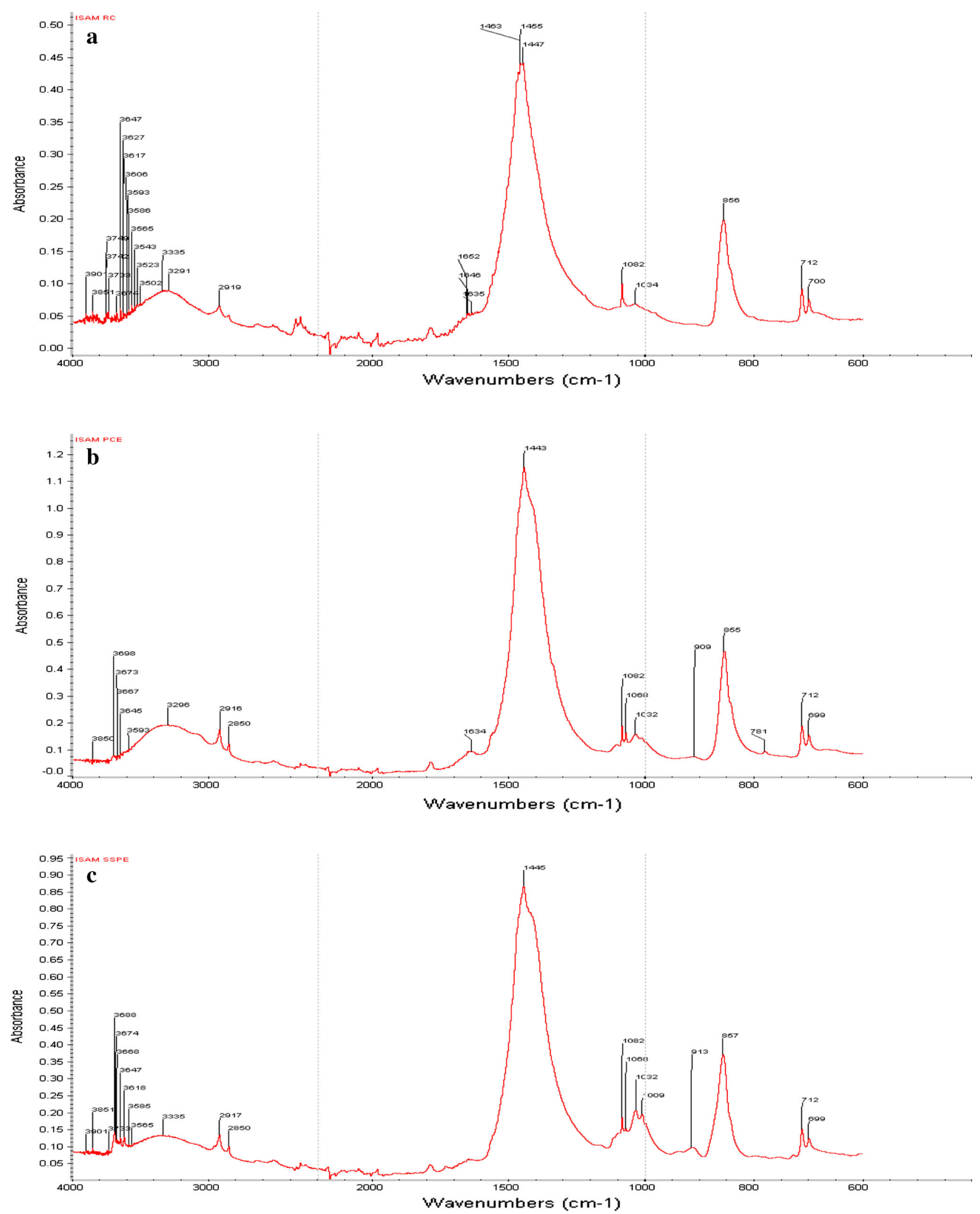

Fig. 5 FTIR spectrum of: a TFS, b TFC and c settled sludge after treatment 

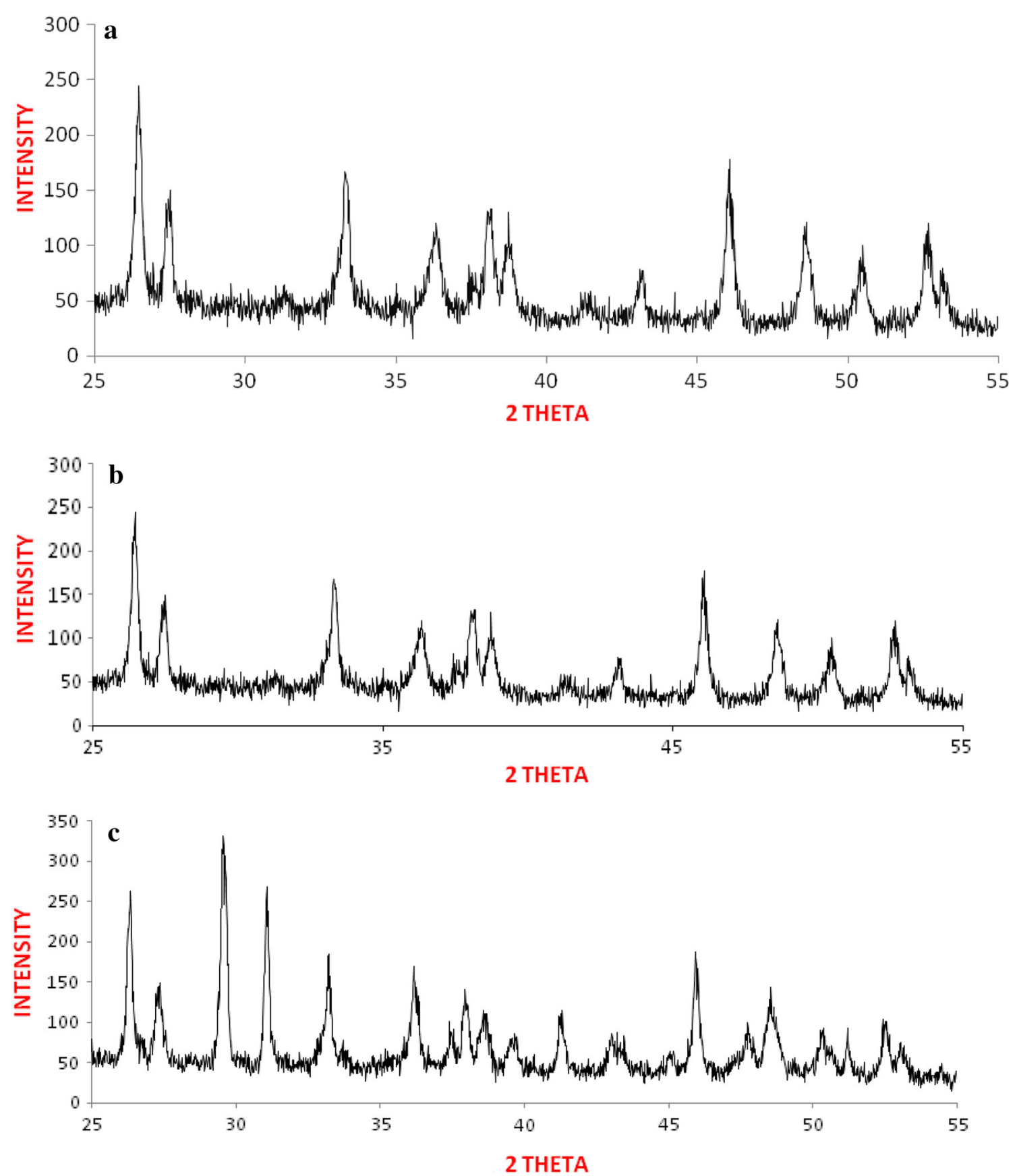

Fig. 6 XRD pattern for: a TFS, b TFC and c settled sludge after treatment

The eutectic points of SSAT due to inhomogeneous deposition of varying suspended and dissolved particles are depicted in Fig. 9a. Moreover, even though Fig. 9a indicates the presence of eutectic points, the process was still exothermic. Figure $9 \mathrm{~b}$ indicates dehydration and volatilization of the samples mass at $310.5^{\circ} \mathrm{C}$, in which about $5 \%(0.11985 \mathrm{mg})$ of its weight was lost [39]. On oxidization, about $10 \%(0.2397 \mathrm{mg})$ of sample weight was lost between 310.5 and $462.5^{\circ} \mathrm{C}$. At $587.5^{\circ} \mathrm{C}, 0.2996 \mathrm{mg}$ was lost. Figure $9 \mathrm{~b}$ shows maximum mass loss of $15 \%$ $(0.2996 \mathrm{mg})$ that ceased at $587.5^{\circ} \mathrm{C}$ [39]. The weight loss was due to potassium $(\mathrm{K})$ chain fragmentation/decomposition with early oxidation of the samples. The samples indicated thermal stability. 
Fig. 7 Graph of a DSC and b TGA of Tympanotonos fuscatus shell
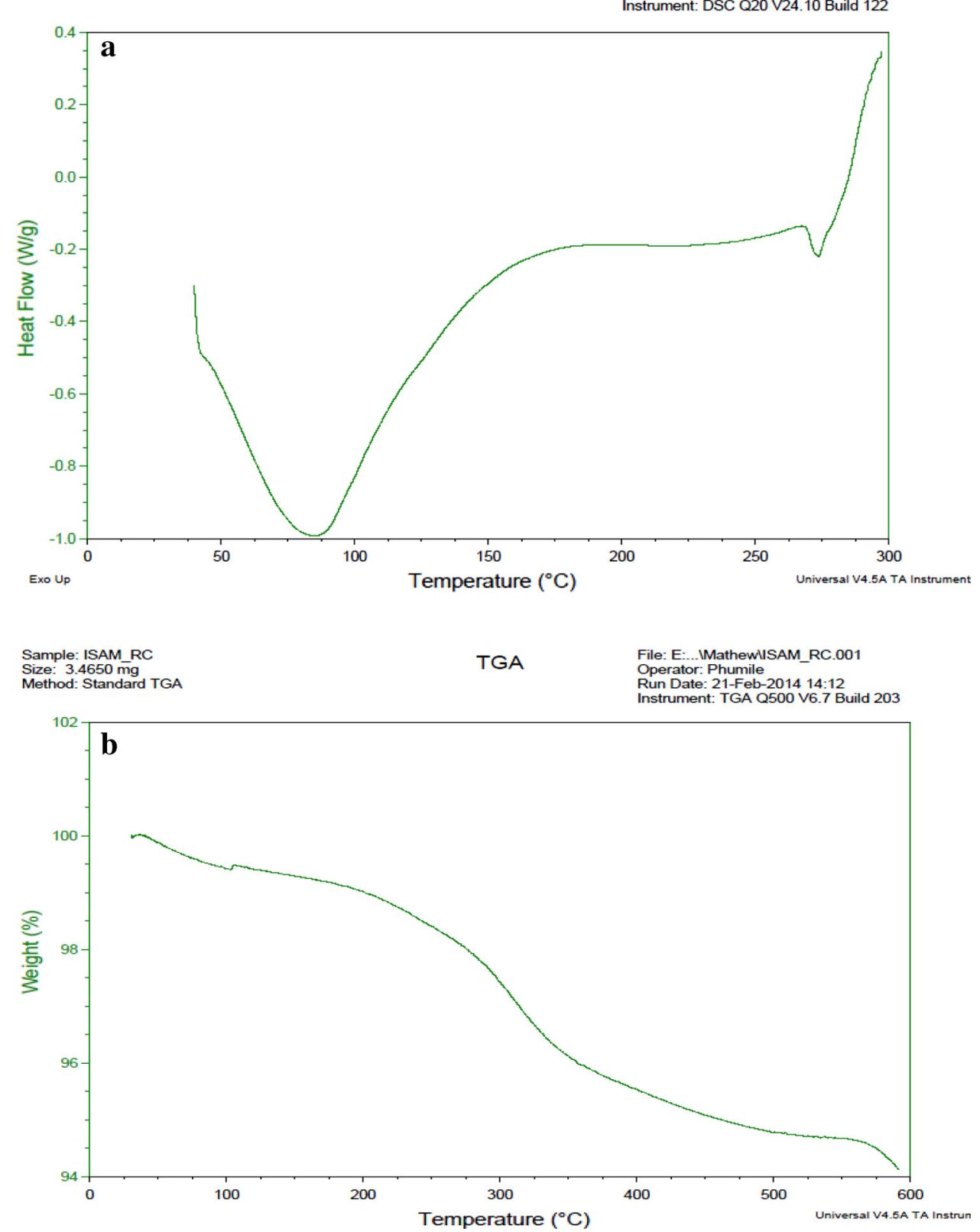

\section{Process factors influence on TFC performance}

\section{Impact of dosage on particle removal efficiency}

Figure 10 shows initial efficiency of $4 \%$ at $0.5 \mathrm{~g} / \mathrm{L}$. This progressively increased to maximum at $46.58 \%$ for $2 \mathrm{~g} / \mathrm{L}$, after which it decreased to $6 \%$ at $5 \mathrm{~g} / \mathrm{L}$. The efficiency increase resulted from incremental provision of TFC +ve charges that progressively destabilize the $\mathrm{PE}-\mathrm{ve}$ charges as dosage increased from 0.5 to $2 \mathrm{~g} / \mathrm{L}$. Furthermore, the decrease observed after $2 \mathrm{~g} / \mathrm{L}$ arose from sustained re-stabilization due to oversupply of +ve charges after $2 \mathrm{~g} / \mathrm{L}$, up to $5 \mathrm{~g} / \mathrm{L}$. At $2 \mathrm{~g} / \mathrm{L}$, there was quantitative equilibrium between both charged species to obtain the optimum performance. Thus, $2 \mathrm{~g} / \mathrm{L}$ was adopted for the evaluation of influence of $\mathrm{pH}$ on particle removal reported in "Impact of $\mathrm{pH}$ on particle removal efficiency".

\section{Impact of $\mathrm{pH}$ on particle removal efficiency}

Figure 11 shows an efficiency profile that alternatively decreased and increased as the $\mathrm{pH}$ reduced from 9 to 2 . The efficiency increase for $\mathrm{pH}$ ranges 3-2 and 8-5 was due to progressive proton donation. Conversely, efficiency suppression for $\mathrm{pH}$ ranges 9-8 and 5-3 could be linked to +ve and - ve species-propelled charge reversal, respectively. 
Fig. 8 Graph of: a DSC and b TGA of Tympanotonos fuscatus coagulant
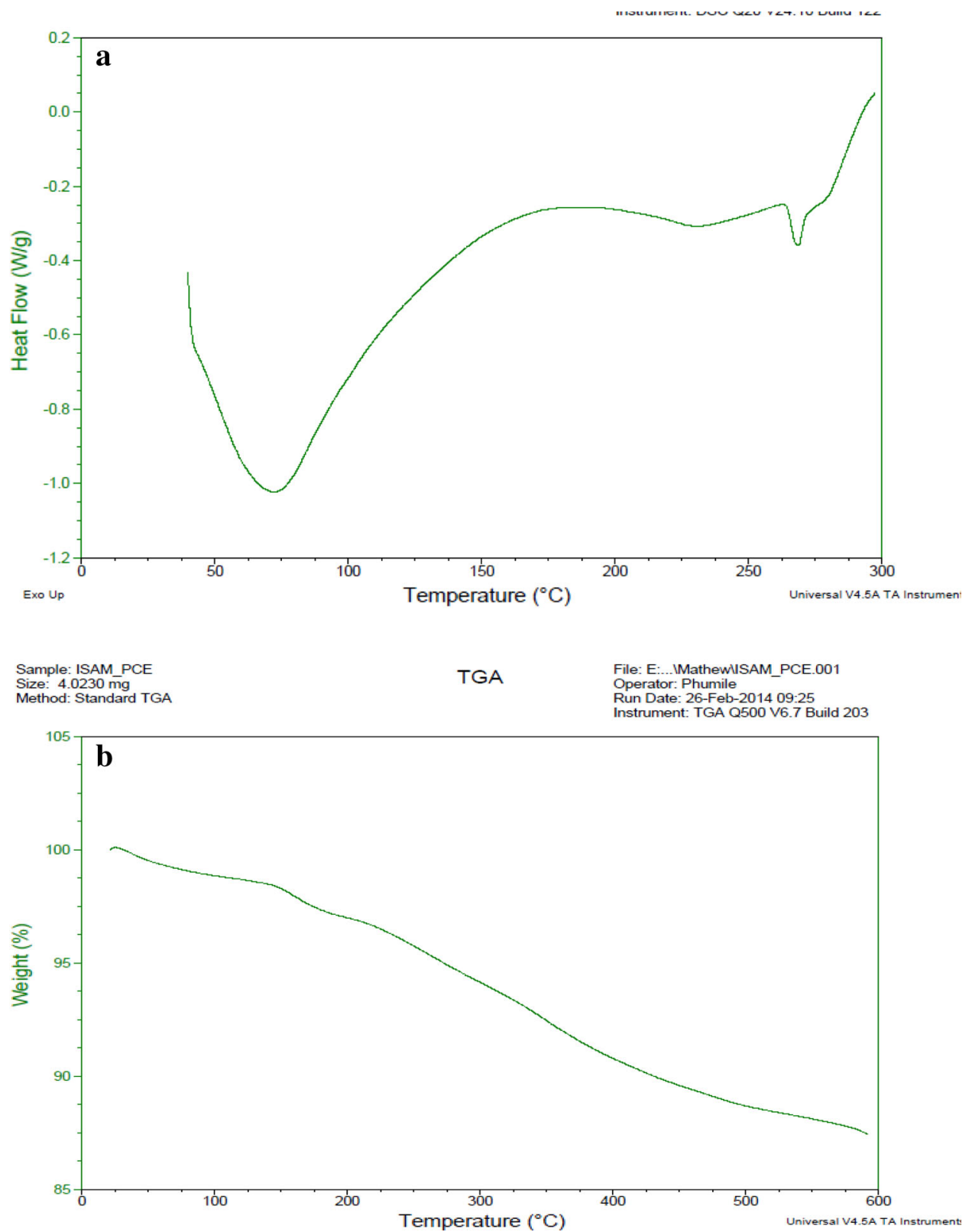

The charge reversal led to re-stabilization and coagulation recession. The peak efficiency at $97 \%$ for $\mathrm{pH} 5$ denotes a regime of equilibrated donation of ions and counter-ions engaged in the perikinetic aggregations.

\section{Temporal variation of efficiency}

Figure 12 depicts the temporal variation of efficiency with reference to $2 \mathrm{~g} / \mathrm{L}$ TFC. It shows time-lined increment in efficiency until $20 \mathrm{~min}$, from which efficiency growth becomes negligible. At $20 \mathrm{~min}$, equilibrium was achieved. Between 0 and $20 \mathrm{~min}$, particle aggregation and gravity settling occurred as destabilization or enmeshment effectively took control of the flocculation.

\section{Coag-flocculation kinetics}

Table 4 shows the kinetic parameter values for $2.0 \mathrm{~g} / \mathrm{L}$ and pH 5. $K_{m}$ was derived from the slope of Eq. (16). $K_{m}$ takes into account the coagulation and flocculation regimes involved in the aggregation for second-order predominated process. In this case, for higher $\alpha$ to be actualized, a lower is obtained. The value of $\alpha$ is in consonance with earlier reports on Brownian coagulation [20, 28]. $\alpha$ is best maintained between 1 and 2 for effective performance. When variation in $K_{\mathrm{R}}$ is negligible, $\varepsilon_{p}$ directly relates to $2 K_{m}=\beta_{\mathrm{BR}}$. In this case, high $\varepsilon_{p}$ results in high kinetic energy to overcome the zeta potential. Low zeta potential ensures recession or total double-layer collapse to actualize 
Fig. 9 Graph of: a DSC and b TGA of settled sludge after treatment

Fig. 10 Removal efficiency vs dosage for Tympanotonos fuscatus coagulant in paint effluent
Sample: ISAM_SSPW Size: $4.0000 \mathrm{mg}$

DSC

File: E:...MathewIDSC DATAUSAM_SSPW.001 Operator: Phumile Instrument: DSC Q20 V24.10 Build 122

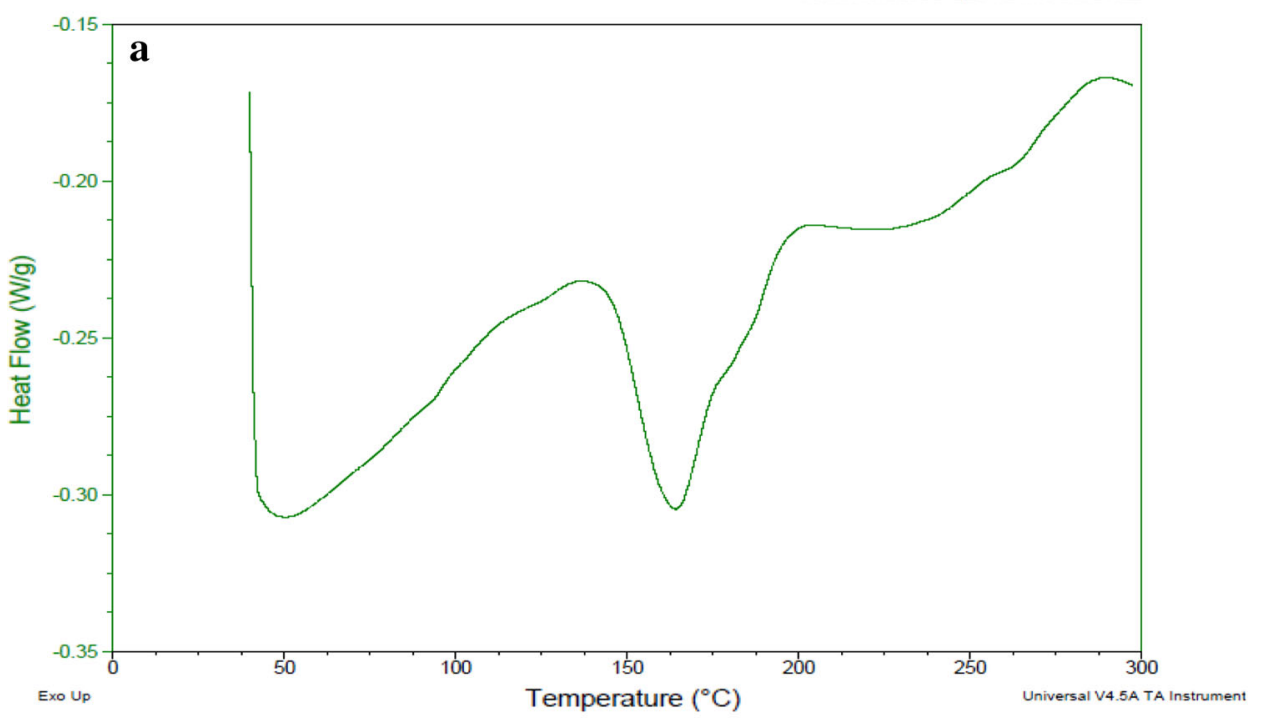

Sample: ISAM_SSPW Size: $2.6280 \mathrm{mg}$

File: E:..MathewUSAM_SSPW.001

Operator: Phumile

Run Date: 21-Feb-2014 16:19 Instrument: TGA Q500 V6.7 Build 203
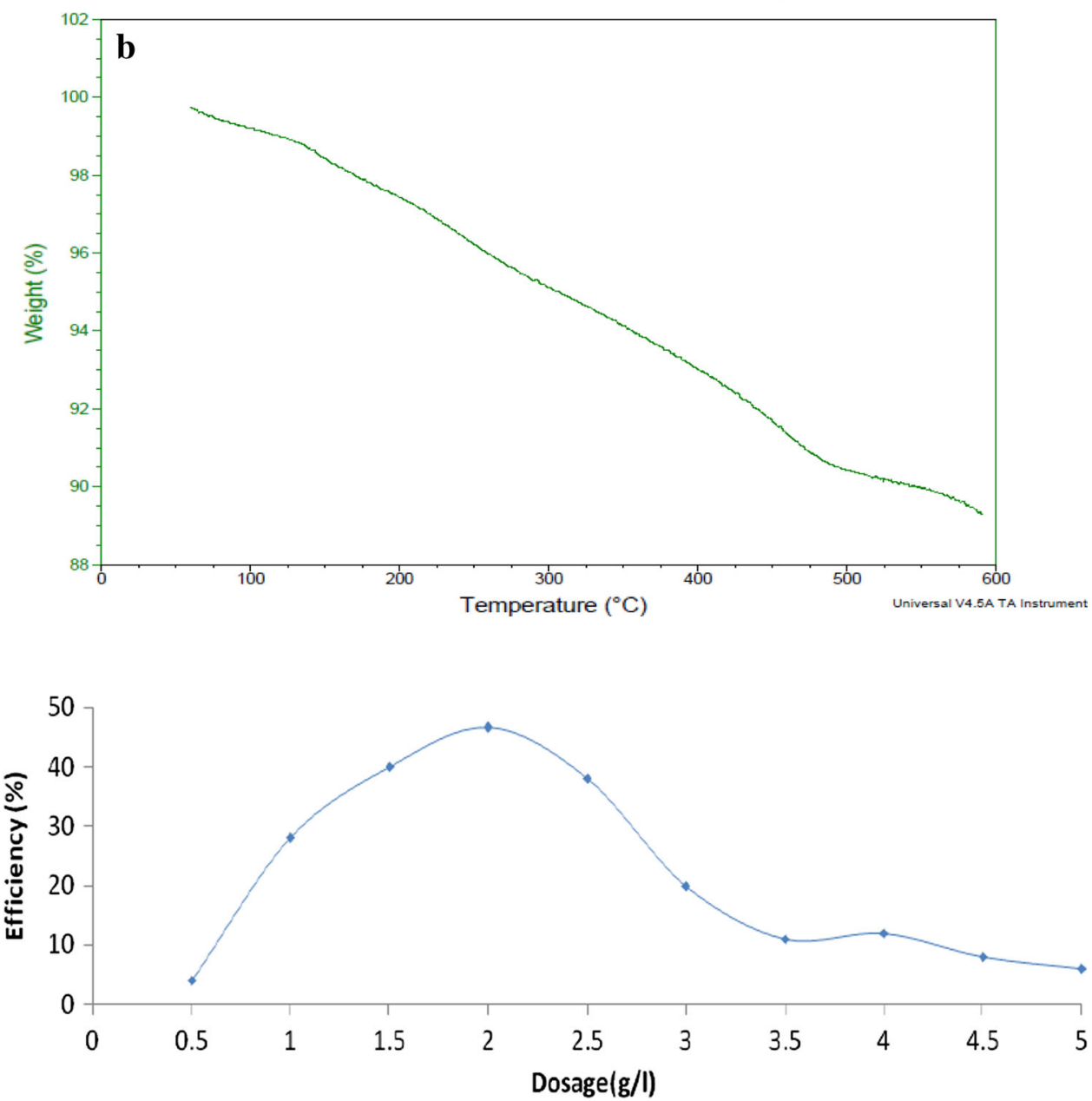


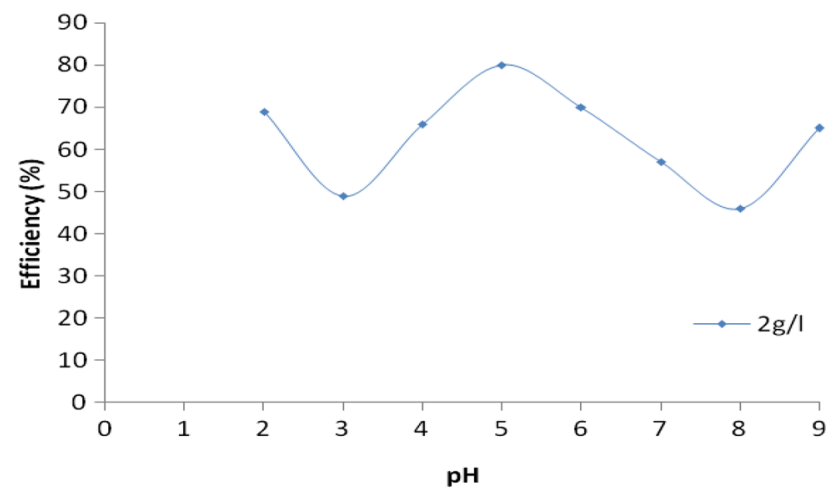

Fig. 11 Optimal condition of $\mathrm{pH}$ on particle removal efficiency at $2 \mathrm{~g} / \mathrm{L}$

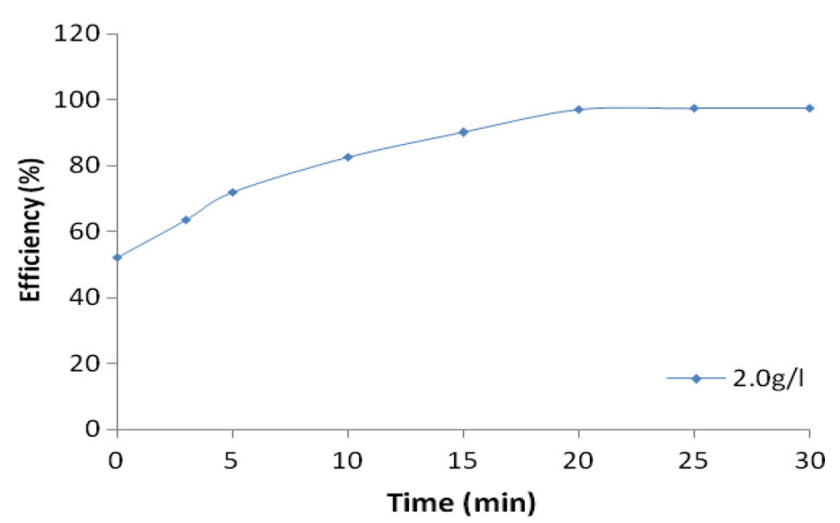

Fig. 12 Variation of efficiency with time at $2 \mathrm{~g} / \mathrm{L}$ and $\mathrm{pH} 5$

Table 4 Coagulation kinetic parameters (pH 5 and $2 \mathrm{~g} / \mathrm{L}$ )

\begin{tabular}{|c|c|}
\hline Parameter & Value \\
\hline$K_{m}\left(\mathrm{~L} \mathrm{~g}^{-1} \mathrm{~s}^{-1}\right)$ & $5.0 \mathrm{E}-5$ \\
\hline$\frac{1}{N_{0}}\left(\mathrm{~L} \mathrm{~g}^{-1}\right)$ & 0.0019 \\
\hline$N_{0}\left(\mathrm{~g} \mathrm{~L}^{-1}\right)$ & 526.30 \\
\hline$R^{2}$ & 0.8576 \\
\hline$\tau_{1 / 2}(\mathrm{~s})$ & 76 \\
\hline$K_{\mathrm{R}}\left(\mathrm{g}^{2} \mathrm{~s}^{-1}\right)$ & $2.55 \mathrm{E}-10$ \\
\hline$\beta_{\mathrm{BR}}\left(\mathrm{L} \mathrm{g}^{-1} \mathrm{~s}^{-1}\right)$ & $1.0 \mathrm{E}-40$ \\
\hline$\stackrel{\circ}{a}_{p}\left(\mathrm{~L}^{3} \mathrm{~g}^{-3}\right)$ & 1958 \\
\hline$D_{p}\left(\mathrm{~g}^{2} \mathrm{~m}^{-1} \mathrm{~s}^{-1}\right)$ & $3.54 \mathrm{E}-05$ \\
\hline$\ddot{U}$ & 2 \\
\hline
\end{tabular}

low $\tau_{1 / 2}$ in favor of high rate of coagulation. The model rate equation at which viable flocs materialize at $2 \mathrm{~g} / \mathrm{L}$ and $\mathrm{pH}$ 5 is displayed in Table 5. The discrepancies occurring in kinetic parameters could be attributed to interplay between van der Waals and hydrodynamic forces, which reduces by factor of 2 the correlation between experimental and theoretical values [19, 24, 40, 41].
Table 5 Rate equation for Tympanotonos fuscatus coagulant in PE

\begin{tabular}{ll}
\hline Dosage $(\mathrm{g} / \mathrm{L})$ & Rate equation $(-r)$ \\
\hline 2 & $5.00 \mathrm{E}-05 \mathrm{Nt}^{2}$ \\
\hline
\end{tabular}

Table 6 Statistical analysis

\begin{tabular}{llllll}
\hline & Av & SD & RMSE & SSE & RE \\
\hline Eff. vs dosage & 21.36 & 14.88 & & & \\
Eff. vs pH & 62.75 & 10.65 & & & \\
EFF. vs time & 81.46 & 16.2 & 0.0352 & 0.2302 & 0.0287 \\
\hline
\end{tabular}

Eff. efficiency

\section{Process variables statistics}

The standard deviation (SD) and statistical error analyses with respect to Figs. 10-12 and Fig. 12, respectively, are represented in Table 6 . The SD values $(14.88,10.65,16.2)$ shown in Table 2 indicate relative volatility in the efficiency profiles of Figs. 10-12 and Fig. 12. The volatility is amply supported by the graph lines and this was due to alternate swings between protonation and de-protonation of the effluent fluid as $\mathrm{pH}$, time and dosage varied. The relative statistical distance of the SD values from zero indicated profound effect of time, dosage and $\mathrm{pH}$ and their capacity to set up aggregation and charge reversal on the process. The results of error analyses with respect to Fig. 12 are shown in Table 6 as RMSE (0.0352), SSE (0.2302), and RE (0.0287). These results indicate how absolute the kinetic data fit the model. The lower the values of RMSE, SSE and RE, the better the fit. Considering the relatively low values of RMSE, Re and SSE, it can be said that the model is reasonably accurate.

\section{Conclusion}

In this work, the coagulation-flocculation process was initiated as a pretreatment method to remove particle load from paint effluent (PE) using Tympanotonos fuscatus coagulant (TFC). At optimum condition, TFC was found to be an effective bio-coagulant in the pretreatment of paint effluent with particle removal efficiency of $97 \%$ at dosage of $2 \mathrm{~g} / \mathrm{L}$ and $\mathrm{pH}$ of 5 . Dosage and $\mathrm{pH}$ had significant influence on the performance of TFC. Rate constant of $5.0 \mathrm{E}-5 \mathrm{~L} \mathrm{~g} \mathrm{~g}^{-1} \mathrm{~s}^{-1}$ was obtained for a period of $76 \mathrm{~s}$. DSC and TGA depicted a thermally stable TFC. SSAT showed a eutectic characteristic, indicating inhomogeneous composition of after treatment sludge (SSAT). The variation in 
chemical compositions of TFC and SSAT indicated the ability of the TFC to uptake pollutants away from the paint effluent. This work demonstrates that TFC has potential for application as a coagulant, and could be extended to other effluents.

Acknowledgments The authors wish to thank the following organizations: Chemical Engineering Department, Nnamdi Azikiwe University Awka, Nigeria; Water Resources Center, Texas Tech University, Lubbock Texas, USA; Fulbright Organization, Institute for International Education, USA.

Open Access This article is distributed under the terms of the Creative Commons Attribution 4.0 International License (http://crea tivecommons.org/licenses/by/4.0/), which permits unrestricted use, distribution, and reproduction in any medium, provided you give appropriate credit to the original author(s) and the source, provide a link to the Creative Commons license, and indicate if changes were made.

\section{References}

1. Akyol, A.: Treatment of paint manufacturing wastewater by electrocoagulation. Desalination 285, 91-99 (2012)

2. Karthik, M., Dafale, N., Pathe, P., Nandy, T.: Biodegradability enhancement of purified terephthalic acid wastewater by coagulation-flocculation process as pretreatment. J. Hazard. Mater. 154, 721-730 (2008)

3. Menkiti, M.C., Nnaji, P.C., Nwoye, C.I., Onukwuli, O.D.: Coagulation-flocculation kinetics and functional parameters response of mucuna seed coagulant of $\mathrm{pH}$ variation in organic rich coal effluent medium. J. Miner. Mater. Charact. Eng. 9(2), 89-103 (2010)

4. Menkiti, M.C., Ndaji, C.R., Ezemagu, I.G., Oyoh, K.B., Menkiti, N.U.: Purification of petroleum produced water by novel afzelia Africana extract via single angle nephlometry. J. Env. Chem. Eng. 3, 1802-1811 (2015)

5. Gregory, J.: Particles in Water: Properties and Processes. IWA Publishing/CRC Press, London (2006)

6. Wang, J., Chen, Y., Ge, X.W., Yu, H.Q.: Optimization of coagulation-flocculation process for a paper-recycling wastewater treatment using response surface methodology. Colloids Surf. A 302(1-3), 204-210 (2007)

7. Liew, G., Noor, M.J.M.M., Muyibi, S.A., Fungara, A.M.S., Muhammed, T.A., Iyuke, S.E.: Surface water clarification using M. Oleifera seeds. Int. J. Environ. Stud. 63(2), 211-219 (2006)

8. Barrera-Diaz, C., Linares-Hernandez, I., Roa-Morales, G., Bilyeu, B., Balderes-Hernandez, P.: Removal of biorefractory compounds in industrial wastewater by chemical and electrochemical pretreatments. Ind. Eng. Chem. Res. 48, 1253-1258 (2009)

9. Miller, S.M., Fugate, E.J., Craver, V.O., Smith, J.A., Zimmerman, J.B.: Towards understanding the efficacy and mechanism of Opuntia spp. as a natural coagulant for potential application in water treatment. Environ. Sci. Technol. 42, 4274-4279 (2008)

10. Crapper, D.R., Krishnan, S.S., Dalton, A.J.: Brain aluminium distribution in alzheimer disease and experimental neurofibrillary degeneration. Science 180(4085), 511-513 (1973)

11. Ezemagu, G.: Nephlometric study of adsorptive and non-adsorptive components of coagulation of produced water and paint effluent using bioextract. M.Sc Dissertation. Nnamdi Azikiwe University, Awka (2015)
12. Tripathi, P.N., Chaundhuri, N., Bokil, S.D.: Nirmali seed a naturally occurring coagulant. Indian J. Environ. Health 18(4) (1976)

13. Al-Samawi, A.A., Shokralla, E.M.: An investigation into an indigenous natural coagulants. J. Environ. Sci. Health Part A Environ. Sci. Eng. Toxic Hazard. Subst. Control 8, 1881-1897 (1996)

14. Menkiti, M.C., Onukwuli, O.D.: Coag-flocculation of mucuna seed coagflocculant (MSC) in coal washery effluent (CWE) using light scattering effects. AICHE J. (2012). doi:10.1002/aic. 12665

15. Gunaratna, K.R., Garcia, B., Andersson, S., Dalhammar, G.: Screening and evaluation of natural coagulants for water treatment. Water Sci. Technol. Water Supply 7(5/6), 19 (2007)

16. Tympanotonos fuscatus. http://www.gastropods.com/2/Shell_ 1612.shtml. Accessed 22 Aug 2015

17. Fernandez, K.: Physiochemical and functional properties of Crawfish Chitosan as affected by different processing protocols. M.Sc Thesis, Dept. of Food Science; Louisiana State University, USA, pp. 1-3, 32-40 (2004)

18. Jamabo, N.A., Chindah, A.C., Alfred, J.F.: Ockiya, length-weight relationship of a Mangrove Prosobranch Tympanotonos fuscatus var fuscatus (Linnaeus 1758 from the bonny estuary, Niger Delta, Nigeria). World J. Agric. Sci. 5(4), 384-388 (2009)

19. Afred-Ockiya, J.F.: Microbial flora of partially processed periwinkles (Tympanotonos fuscatus) from local markets in Port Harcourt, Nigeria. Niger. J. Aquat. Sci. 14, 51-53 (1999)

20. Menkiti, M.C., Nnaji, P.C., Onukwuli, O.D.: Coag-flocculation kinetics and functional parameters response of periwinkle shell coagulant (PSC) to $\mathrm{pH}$ variation in organic rich coal effluent medium. Nat. Sci. 7(6), 1-18 (2009)

21. Verma, S., Prasad, B., Mishra, I.M.: Pretreatment of petrochemical wastewater by coagulation and flocculation and the sludge characteristics. J. Hazard. Mater. 178, 1055-1064 (2010)

22. Clesceri, L.S., Greenberg, A.E., Eaton, A.D.: Standard Methods for the Examination of Water and Waste Water, 20th edn. APHA, USA (1999)

23. Metcalf and Eddy: Physical unit process, waste water engineering treatment and reuse, 4th edn. Tat-McGraw Hill, New York (2003)

24. Swift, D.L., Friedlander, S.K.: The coagulation of hydrolysis by Brownian motion and laminar shear flow. J. Colloid Sci. 19, 621 (1964)

25. Jin, Y.: Use of high resolution photographic technique for studying coagulation/flocculation in water treatment. M.SC Thesis, University of Saskatchewan, Saskatoon, Canada, pp. 22-29 (2005)

26. Holthof, H., Egelhaaf, S.U., Borkovec, M., Schurtenberger, P., Sticher, H.: Coagulation rate measurement of colloidal particles by simultaneous static and dynamic light scattering. Langmuir 12, 5541 (1996)

27. Von Smoluchowski, M.: Versucheiner MathematischenTheorie der Koagulations Kinetic KolloiderLousungen. Z. Phys. Chem. 92, 129-168 (1917)

28. VanZanten, J.H., Elimelechi, M.: Determination of rate constants by multi angle light scattering. J. Colloid Interface 154(1), 1-7 (1992)

29. Hunter, R.J.: Introduction to Modern Colloid Science. Oxford University Press, New York (1993), pp. 33-38;289-290

30. (WST) Water Specialist Technology: About coagulation and flocculation. Inf. Bull. USA 1-10 (2003)

31. Santos, E.V., Rocha, J.H.B., Medeiros de Araújo, D., Chianca de Moura, D., Martínez-Huitle, C.A.: Decontamination of produced water containing petroleum hydrocarbons by electrochemical methods: a minireview. Environ. Sci. Pollut. Res. 21, 8432-8441 (2014) 
32. Igunnu, E.T., Chen, G.Z.: Produced water treatment technologies. Int. J. Low Carbon Technol. 9, 157-177 (2014)

33. Stuart, B.H.: Infrared Spectroscopy: Fundamentals and Application, pp. 71-93. Wiley, USA (2004)

34. Haines, P.J.: The Royal Society of Chemistry, Cambridge (2002)

35. Brukh, R., Mitra, S.: Kinetics of carbon nanotube oxidation. J. Mater. Chem. 17, 619-623 (2007)

36. Vyazovkin, S.: Thermogravimetric Analysis, Characterization of Materials, 2nd edn, pp. 1-12. Wiley, USA (2012)

37. Ramani, K., Jain, S.D., Mandal, A.B., Sekaran, G.: Microbial induced lipoprotein biosurfactant from slaughterhouse lipid waste and its application to the removal of metal ions from aqueous solution. Colloids Surf. B Biointerfaces 97, 254-263 (2012)

38. Menkiti, M.C., Aneke, M.C., Ejikeme, P.M., Onukwuli, O.D., Menkiti, N.U.: Adsorptive treatment of brewery effluent using activated Chrysophyllum albidium seed shell carbon. SpringerPlus 3, 213 (2014)

39. Verma, S., Prasad, B., Mishra, I.: Pretreatment of petrochemical wastewater by coagulation and flocculation and the sludge characteristics. J. Hazard. Mater. 178, 1055-1064 (2010)

40. Holthof, H., Schmitt, A., Barbero, F., Borkovec, M., Vilehez, C., Schurtenberger, P., Hidalgo-Alvarez, R.: Measurement of absolute coagulation rate constants for colloidal particles: comparison of single and multiparticle light scattering techniques. J. Colloid Interface Sci. 192, 462-470 (1997)

41. Ugonabo, V.I., Menkiti, M.C., Onukwuli, O.D.: Effect of coagflocculation kinetics on Telfairia occidentalis seed coagulant (TOC) in pharmaceutical wastewater. Int. J. Multidisp. Sci. Eng. 9 (2012) 